\title{
The Scotland Act 2012: The Next Phase of Devolution in Scotland and its Potential Impact on Wales
}

Le Scotland Act (2012) : prochaine étape de la dévolution en Écosse et possible impact sur le pays de Galles

\section{Elizabeth Gibson-Morgan}

\section{OpenEdition \\ Journals}

\section{Electronic version}

URL: http://journals.openedition.org/etudesecossaises/849

DOI: 10.4000/etudesecossaises.849

ISSN: 1969-6337

\section{Publisher}

UGA Éditions/Université Grenoble Alpes

\section{Printed version}

Date of publication: 15 April 2013

Number of pages: 141-158

ISBN: 978-2-84310-246-2

ISSN: 1240-1439

\section{Electronic reference}

Elizabeth Gibson-Morgan, "The Scotland Act 2012: The Next Phase of Devolution in Scotland and its Potential Impact on Wales", Études écossaises [Online], 16 | 2013, Online since 15 April 2014, connection on 15 March 2021. URL: http://journals.openedition.org/etudesecossaises/849; DOI: https://doi.org/10.4000/etudesecossaises.849 


\section{The Scotland Act 2012: The Next Phase of Devolution in Scotland and its Potential Impact on Wales}

The UK has undergone fundamental constitutional change in the last fifteen years or so which makes it a very different Union. In the words of Alan Taylor of The Scotsman: "On May 6th 1999, Scotland voted for its first parliament in almost three hundred years, an event of huge significance not only for Scots but for people throughout Great Britain."1 Indeed, the year 1999 saw the official opening of the Scottish Parliament and through it the strengthening of the Scottish Nation following the implementation of the Scotland Act $1998^{2}$ on devolution. The 1998 Act was to serve as the legal framework of Scottish devolved institutions for the next ten years. But even more important, at least for the Scots, it provided the Scottish people with its own democratically-elected representative body. The latter also benefited from a strong legitimacy as it had been approved by the Scottish people themselves who were asked in a referendum held in Scotland in 1997 whether such a Parliament should be established. In the same referendum they were also consulted about whether the Scottish legislature should be given tax-varying power. Although support for the latter was lower and more volatile during the campaign, the vote proved to be clearly in favour of devolution. On the first question, a Scottish Parliament was endorsed by $74.3 \%$ to $25.7 \%$ and there was also a clear majority in favour of giving the Scottish Parliament tax-varying powers $(63.5 \%$ against $36.5 \%)$. Yet, taxation and government borrowing powers were to be reserved matters under schedule 5 of the Scotland Act 1998 as the Scottish Parliament was not set up as a sovereign legislature but as a delegated authority, whatever its degree of legitimacy. The whole devolution process was not conceived as a transfer

1. A. Taylor, What a State! Is Devolution for Scotland the end of Britain?, London, HarperCollins, 2000, p. IX.

2. It received Royal Assent on 19 November 1998. 
of sovereign powers and has been subject to the respect of the sovereignty of the Westminster Parliament from the start. The golden rule was that no other parliament at sub-national and national levels would compete with Westminster.

"A Parliament", as Dawn Oliver has explained, "is a meeting at which discussion takes place" (Oliver, 1998, p. 3), reflecting on the very meaning of the term and its origin - the French word parler. It must not only be a forum for debates but an instrument able to act. Indeed, one of the strategic roles of Parliaments, apart from their scrutiny of legislation, is their ability to vote financial Bills. The birth of the United States of America as an independent nation arose from the rebellion of the Thirteen colonies against taxation imposed upon them by the British without representation. Over two centuries later, the UK Government was to deprive the Upper House of the Westminster Parliament - the House of Lords - of the power to debate, scrutinize or vote money bills (under the 1911 Parliament Act). From then on, the Commons have benefited from a financial privilege denied to the Lords. The House of Lords emerged as a weaker house without power to tax or spend and as a House unrepresentative of the people. More than a century later a draft House of Lords Reform Bill_-session 2010-2012_aimed at making the Upper House more representative through direct election but without giving it more powers. It did not include any provision that might put an end to the financial privilege of the Commons by reinstating the right of the House of Lords to examine money bills. The uncompromising principle is not to alter the supremacy - including in financial aspects - of the House of Commons. As Gerry Holtham stated in the second and final report of the Holtham Commission for Wales published on July 2010: "No area could be more essentially political than taxation.” (Holtham, 2010, p. 1)

The Scottish (single-chamber) legislature for its part was given a general law-making power to legislate for Scotland except in "reserved areas" but was denied direct financial resources, thus confirming its subordinate status. Part 4 of the Scotland Act 1998 gave the Scottish Parliament only limited power to amend its budget through taxation. ${ }^{3}$ Indeed, by exercising the power to vary the basic rate of income tax in Scotland - the Scottish Variable Rate (SVR) - the Scottish Parliament may raise or cut the basic rate by up to three pence in the pound. At the time of writing it has never been used by Members of the Scottish Parliament (MSPs) as

3. For Dylan Griffiths of the Constitution Unit School of Public Policy, "the granting of taxvarying powers to the Scottish parliament may be only symbolic for now but it is a significant expression of the stature of the new parliament" (D. Griffiths, "Second Coming. The Devolution Revival", in G. Girard and M. Graves (eds), Europe unie: Le Royaume désuni? Les enjeux de la dévolution, Brest, Université de Bretagne occidentale, 2000, p. 21). 
they do not seem to be convinced Scotland has anything to gain from it. Besides, limited financial autonomy for Scotland was not initially considered as a priority. The debate about devolution has, since 1999, focused on the constitutional and legal framework binding Scotland, Wales and Northern Ireland within the United Kingdom. Although constitutional reform is vital for the future of Scotland - and Wales - it is fundamentally underpinned by the need to clarify the division of financial responsibilities between UK and devolved Scottish and Welsh levels, all the more as the financial relationship between Scotland and Wales and Westminster has been uncertain for several years. What is at stake is not only the future of the devolution process in Scotland and Wales but also the future of the United Kingdom as a Union of four nations. The latter is likely to undergo further fundamental changes under the impact of the impending independence referendum on Scotland in 2014, ${ }^{4}$ the review of devolution in Wales through the Silk Commission, ${ }^{5}$ and the reform of the composition of the House of Lords, all of which might lead to a looser Union.

The last election to the Scottish Parliament in 2011 saw the unprecedented victory of the Scottish National Party (SNP) with 69 of the 129 seats, securing the first overall majority for any party since the establishment of the Scottish legislature in 1999. The SNP leader, Alex Salmond, has committed himself to holding an independence referendum, thus sparking a constitutional debate. The current paper will examine the effect the Scotland Act 2012 - "an Act to amend the Scotland Act 1998 and make provisions about the functions of the Scottish ministers, and for connected purposes" - is likely to have not only on Scotland, but also on Wales and on the future of the United Kingdom. The latter will very much depend on the outcome of two key referendums: the first one to be held in Scotland in 2014 asking Scottish people whether they want Scotland to be independent from the United Kingdom or not, and the other one, an in/out referendum on Britain's membership of the European Union by the end of 2017 (after the next general election of 7 May 2015).

4. At the time of writing, Alex Salmond was believed to favour Saturday 14 October 2014, but had yet to formally confirm the date. In any case it is supposed to be held before the end of 2014 .

5. On 11 October 2011, an independent cross-party Commission on Devolution in Wales, named after its chairman Paul Silk - a former clerk to the National Assembly for Wales - similar to the Calman Commission in Scotland was set up to examine how the Welsh government was funded and to make recommendations on Welsh devolved finances and "financial accountability". It was expected to report on the financial aspect of the Welsh devolution by the end of 2012 and it has just published its first report, but it is also due to issue recommendations on devolving further functions regarding this time the constitutional settlement in Wales in 2013. 


\section{The political and financial background to the Scotland Act}

Devolution has been a real success which works well in practice. The Scottish Parliament has embedded itself in both the constitution of the UK and the consciousness of Scottish people. It is here to stay. ${ }^{6}$

It is on this positive note that the Commission on Scottish Devolution, more commonly known as the Calman Commission and set up in December 2007, concluded its final report that included 63 recommendations published in June 2009. The Commission chaired by Sir Kenneth Calman was to review the provisions of the Scotland Act 1998 in the light of the first ten years of experience of the Scottish Parliament and to consider how devolution for Scotland could further develop. The Calman Commission, a cross-party commission of opposition parties within the Scottish Parliament was in a way to provide a counter-proposal to the National Conversation on Scotland's constitutional future initiated by the SNP Scottish Government and which envisaged the independence of the country as an option. The SNP had formed a minority government after the 2007 Scottish Parliament elections and thus became emboldened by its political breakthrough. The Calman Commission was set up with the aim of securing Scotland's place in the Union as a response to the motion passed by opposition parties in the Scottish Parliament calling for an independent review of devolution. Its terms were:

To review the provisions of the Scotland Act 1998 in the light of experience and to recommend any changes to the present constitutional arrangements that would enable the Scottish Parliament to serve the people of Scotland better, that would improve the financial accountability of the Scottish Parliament and that would continue to secure the position of Scotland within the United Kingdom. ${ }^{7}$

In June 2009, the cross-party Commission reported on possible adjustments to the devolution settlement, including important proposals on fiscal powers. In its report entitled Serving Scotland Better: Scotland and the United Kingdom in the 21st century, it recommended a whole range of new devolved powers over taxation and borrowing. A key principle was to make the Scottish Parliament not only politically accountable - as was already the case, MSPs having to face elections every four years — but also financially accountable. Thus, the Commission recommended strengthening financial accountability by allowing greater variation of income

6. House of Commons Library, The Commission on Scottish Devolution - The Calman Commission, SN/PC/04744, 4 June 2010, p. 14.

7. <www.commissiononscottishdevolution.org.uk> (consulted on 27 April 2012). 
tax, devolving other taxes and by giving greater borrowing powers to Scottish ministers. So the objective that underpinned the whole work of the Commission was not only to make the Scottish Parliament more responsible and accountable to the people it represents through new devolved powers over taxation and borrowing, but also to provide an alternative to independence in order to strengthen devolution and the Union itself. It was all the more important as there were- and still aremany uncertainties linked to the referendum on the independence of Scotland due to be held in 2014.

The Calman Commission's report was welcomed by the UK Labour Government of Gordon Brown which was determined to introduce legislation to give effect to the majority of its recommendations. To that purpose, a cross-party working group in charge of the implementation of the proposals was set up and produced a White Paper entitled Scotland's future in the UK: building on 10 years of Scottish Devolution on 25 November 2009. The Labour Party having lost its majority in the House of Commons following the 2010 General Election could not take forward the proposals of the Calman Commission as it had planned to do. Yet, the Conservative-Liberal Democrat Coalition Government that emerged from the 2010 General Election committed itself in turn to implement the proposals of Calman. In The Coalition: Our Programme for Government published in May 2010, the 24th issue, headed "Political Reform", read: "We will implement the proposals of the Calman Commission and introduce a referendum on further Welsh devolution." The Scotland Act 2012 was the result of this commitment. It was therefore presented by the current Coalition Government as its legislative response to the report of the Calman Commission. The Scotland Act aims at improving the existing arrangements for the governance of Scotland by handing over new powers to the Scottish Parliament. It is a step towards a more fiscally decentralised United Kingdom. Thus before examining the financial changes introduced by the new Act, a short reminder of the current financing of devolution in Scotland will be provided.

\section{The current financial arrangements: financing Scottish devolution prior to the Scotland Act}

Currently, the Scottish Parliament but also the National Assembly for Wales are not accountable for raising revenue. Indeed, at present, in Scotland and Wales, virtually all the resources of devolved governments come from a grant from the UK Government and not from the Scottish or the Welsh people. Taxation is centrally collected. Indeed, the 
central government allocates resources to the different parts of the UK according to its own priorities and not to the needs of each nation. The grant from the central government better known as the Barnett formula which is based on population and not related to public spending needs in Scotland or Wales, tends to be overgenerous to Scotland and unfair to Wales. This formula was originally introduced as a provisional arrangement, as Michael O'Neill explained: "the Barnett formula, like other aspects of the devolution settlement, was carried over from the old system of administrative devolution" adding that "fiscal pressure more generally will lead to demands to reopen the settlement". ${ }^{8}$ It is a source of inequalities and distortions between the devolved nations and between the devolved bodies and the central government. Thus, Scotland and Wales are still financially dependent on the central government and if initially the Barnett formula guaranteed Scotland and Wales predictable revenues as the institution of devolved government in Scotland - and Wales - was followed almost immediately by a period of extensive growth in expenditure in England on the functions devolved to the Scottish and the Welsh governments, cuts in spending under austerity budgets in the public sector on which Scotland and Wales heavily depend have made them less so, hence a growing opposition to the Barnett formula particularly in Wales. Severely constrained public finances in England have raised many questions about the overall fiscal framework of devolution in Scotland and Wales. To reverse the slogan of the American colonists in 1776, there can be no representation without taxation. Devolutionists for their part have long argued that it is paradoxical to give wide powers of autonomy to a Scottish Parliament and a Welsh Assembly, but to deny them direct financial resources. At the moment the Scottish and Welsh legislatures spend money from the block grant which they do not raise, and for which they are not accountable to their electors. It diminishes them as democratic assemblies and is at the origin of a lack of transparency. As Alan Trench of the Constitutional Unit observed commenting on the Holtham Commission's report in July 2010:

A government that spends money but has no responsibility for raising it does not make its voters bear the full burden of its decisions. A devolved government needs to be more than just an elected spending agency, if it is to be properly accountable. ${ }^{9}$

Besides, under purely pragmatic financial considerations, the divergence between the spending power and the revenue-raising power of any

8. M. O'Neill, Devolution and British Politics, London, Pearson-Longman, p. 329.

9. A. Trench, "Conservative Radicalism in Wales", Public Finance, Issue 11, November 2012. 
public authority should be limited as far as possible. So what is really at stake is how to enhance the transparency of the process by which the Scottish Parliament and the National Assembly for Wales are funded. The government's Scotland Act directly raises this issue for the first time. It focuses on a more consistent way of funding devolution across Britain while allowing the UK Government to go on determining overall spending and borrowing limits. As the Secretary of State for Scotland, Michael Moore, explained in a written ministerial statement while the Scotland Bill was being introduced:

Once the measures are fully implemented the Scottish Parliament and Scottish ministers will have more powers, will be more accountable, and will be better equipped to respond to Scotland's needs within the United Kingdom. ${ }^{10}$

Scotland and Wales for their part have both expressed a preference for a funding regime combining a needs-based block grant with a degree of tax devolution.

\section{The Scotland Act-described by Alan Trench as "the first substantial change to devolution for Scotland since 1999"}

On St Andrew's Day - 30 November 2010 - a Bill was introduced in the House of Commons defined as "a Bill to amend the Scotland Act 1998 and make provision about the functions of the Scottish ministers; and for connected purposes". So what has become the Scotland Act works primarily by amending the Scotland Act 1998 and goes further than the recommendations of the Calman Commission. In fact, the Act strengthens the devolution settlement in Scotland and increases the financial accountability of its Parliament. The objective of the Act is to increase the Scottish Parliament's ability to make autonomous choices that benefit the people of Scotland and to be accountable for these choices. Its financial provisions are designed to reduce Scotland's dependence on UK tax and revenues. The Scotland Act makes changes to the devolution settlement for Scotland largely but not exclusively based on the recommendations of the Commission on Scottish Devolution or Calman Commission. Some provisions in the Act are directly derived from these recommendations; others have been left out such as the recommendations for social security and welfare reform. Thus, the Scotland Act did not follow all the recommendations of the Calman Commission and covered other issues, especially constitutional ones. The Act is divided into four parts:

10. <www.scotlandoffice.gov.uk> (consulted on 27 April 2012). 
part 1 concerns the Scottish Parliament and its powers; part 2 concerns the Scottish ministers and their powers; part 3 covers Finance, whereas part 4, entitled "Miscellaneous", contains a clause on sentencing policy as well as matters such as interpretation and commencement. The Act includes 39 clauses of which 9 set out finance provisions, including 6 clauses relating to changes to the tax system that will be implemented by secondary legislation; all the other clauses are devoted to constitutional issues. Even if part 3 is shorter than the rest of the provisions, it is one of the most sensitive ones as it deals with a highly strategic issue, finance, as well as being a strong symbol of sovereignty. It is all the more important in the current context of the financial crisis where governments try to steer their economies out of the recession. Part 3 covers not only taxation-different kinds of Scottish taxes falling within the scope of the Scottish Parliament's power to legislate- but also borrowing by the Scottish ministers. In a nutshell, elements of taxation will be devolved, there will be a reduction in the block grant and extended borrowing powers will be introduced.

It received second reading in the Commons with Opposition support on 27 January 2011, then it was considered in Committee of the Whole House from 7 March to 15 March 2011. The report stage and third reading took place on 21 June 2011. Throughout its legislative process in the Commons it benefited from an all-party agreement. Then it was sent to the House of Lords for consideration. It passed its second reading in the Lords, with much consensus save from one or two senior Scottish Conservative devolutionists like Michael Forsyth and Ian Lang, both, former Scottish Secretaries. The former tabled in an amendment in the Lords to ensure that a referendum is held before the financial provisions in the Act are put into effect. Further amendments were made in the Upper House including during the third reading. A significant one stated that "the holding of a referendum on whether Scotland should become independent from the rest of the United Kingdom is outside the legislative competence of the Scottish Parliament". Labour peers, including those from England and Wales, were almost unanimously in favour. Finally, on 30 April 2012, the Bill was returned from the Commons with the Lords' amendments agreed to. After having been voted by the two houses in identical terms, the text was formally approved by the monarch as it received Royal Assent on 1 May 2012. The 2012 Act was thus submitted to detailed scrutiny and a fairly long parliamentary process based on a consensual approach. 


\section{The content of the 2012 Act regarding fiscal changes}

Certain taxes will be Scottish-raised but with Westminster's approval. The idea is to substitute a proportion of the block grant - the current main source of funding for the Scottish Parliament - with the power of the Scottish Parliament to raise revenues through some taxes and so exercise some fiscal responsibility. The Scottish Parliament would be given the power to raise additional income tax to make up as much revenue as it sees fit. The Act creates a new Scottish rate of income tax which will apply alongside the existing UK-wide rate of income tax and is due to be in place for Scotland's fifth devolved Parliament in 2015. The financial provision of the Act will allow the Scottish Parliament to raise more of the money it spends. It will enable the Scottish government to raise or cut income tax by up to $50 \%$ at the basic rate and $20 \%$ at the highest. The Scottish Parliament would be responsible for raising - that is to say would control - approximately $£ 12$ billion or $35 \%$ of the revenue it spends, up from the current $15 \%$, with the remaining $65 \%$ coming from the UK Block Grant. The block grant from the Treasury, worth £29 billion a year, would be reduced by an equal amount, while elements of taxation would be devolved. The Scottish Parliament would have to determine and levy taxes to make up its budget and extended borrowing powers would be introduced to compensate for the loss.

So the guiding principle was not to abolish existing arrangements but to build on them. It meant that the structure and thresholds of the wider UK income tax system, which remains a reserved matter, would be retained. The block grant itself would be kept but proportionately adjusted; Lord Barnett, who has given his name to the formula for the assessment of the block grant given to Scotland back in 1978 has joined with Lord Forsyth to propose that the allocation of resources to Scotland should be on the basis of need rather than population. Section 28 of Part 3 of the Scotland Act reads:

The UK Government is providing for the Scottish Parliament to set a rate of income tax for Scottish taxpayers; it is devolving stamp duty land tax and landfill tax to Scotland and it is making provision for new devolved taxes.

As it is clearly stated, the Scottish Parliament will be able to introduce new taxes specific to Scotland-Scotland-only taxes - to create further revenue but with Westminster's approval. The main innovation is a Scottish rate of income tax instead of the Scottish Variable Rate (SVR) which was introduced by the Scotland Act 1998. In fact, the Scottish rate of income tax is a generic term which covers three different rates - the Scottish basic rate, the Scottish higher rate and the Scottish additional rate- 
to be paid by Scottish taxpayers. ${ }^{11}$ The Scottish income tax will apply only to income from earnings, pensions and other non-savings sources and will be introduced from 6 April 2016.

The UK version of the taxes will no longer apply in Scotland and the Scottish Parliament will be able to replace them with taxes of a similar nature set at its own chosen rate. The Scotland Act 2012 enables the Scottish legislature to vary the rate of income tax and create new taxes as well as providing Scottish ministers with new borrowing powers for the first time. The agreement between the UK and Scottish governments about the Scotland Act will result in the Scottish Government gaining extensive new borrowing powers. Indeed, if a government raises its own revenue, it needs to be able to borrow to cope with fluctuation in its income as a result.

\section{Borrowing powers}

The Scotland Act will enhance the Scottish Government's capital borrowing powers. The Calman Commission and the Scottish Parliament agreed that Scottish Ministers should receive new borrowing powers as part of their increased responsibility and accountability, with the agreement of the UK Government, for capital and current expenditure, subject to Treasury controls and limits. Under Part 3, clause 37, "Scottish Ministers" are able to borrow "subject to HM Treasury's controls and limits". They can borrow $£ 2.2$ billion from 2013 for capital spending and $£ 500$ million for shortfalls in income tax revenues. The Scotland Act was not intended to pave the way for independence while it increases the freedom of action of the Scottish Parliament and Government, the Scottish Parliament would still depend on a block grant from the United Kingdom. Besides, the existence of Scottish devolved bodies would still depend on the Scotland Act 1998 which can theoretically be repealed at any time by the Westminster Parliament as other ordinary pieces of legislation or statutes voted by the British Parliament under the doctrine of parliamentary sovereignty. Finally, the latter retains its right to legislate for Scotland - it is still the only Parliament that is sovereign and can legislate for the whole of the United Kingdom.

11. New sections $80 \mathrm{D}$ to $80 \mathrm{~F}$ were incorporated into the Scotland Act 1998 to define who will be a Scottish taxpayer for the purpose of the Scottish rate. 


\section{Reactions to the Scotland Act}

Although there was little opposition to the Scotland Act - the three Unionist parties in the Scottish Parliament are in favour of the Act - some of its financial provisions may prove to be contentious. Thus, the requirement for the Scottish Parliament to set its own rate of income tax will increase its accountability, but raises fears about higher taxes in Scotland. Besides, the proposed total limit of borrowing $£ 2.2$ billion was highly criticised by the Scottish Government notably in its official response to the recommendations of the Commission on Scottish Devolution. ${ }^{12}$ It was considered too low by Scottish authorities to make a meaningful difference and to fund Scotland's infrastructure investment programme in transport, health, education, local government, housing or even prisons. The provisions of the Scotland Act are likely to generate conflict with the Scottish government on many issues, such as the precise Scottish share of the block grant, the relationship of Scottish borrowing to the UK National Debt, and the desire for other wider taxes. As Alan Trench explained: "It is clear that fiscal devolution needs to go a lot further than the Scotland Act 2012 does if it is to meet the aspirations of the people of Scotland or put the Scottish government in a position to make its own policy choices." 13 The proposals over Scottish income tax have indeed been criticised for not including other taxes such as corporation tax or, more importantly taxes in relation to the Scottish oil industry.

In October 2012, the Silk Commission for its part held a rather different view, excluding the idea of devolving corporation tax to the Welsh Assembly as it considered that "the costs would outweigh the benefits". There has also been debate about who precisely would pay Scottish income tax. It should be noted, too, that Scotland would spend its own income tax but that the rates, bands and impact would be laid down by Westminster. The Scots would not be able to determine whether to have a more progressive tax rate. Treasury control from Westminster would still prevail.

Devolution is a process based on permanent adjustments. Scotland and to a slightly lesser extent Wales, have experienced a momentum for change since the first elections to the devolved Parliament and Assembly in 1999. Of the two Celtic nations (Wales and Scotland) Scotland has known the more advanced form of devolution as the Scottish Parliament was given primary legislative power from the start whereas the Welsh

12. <www.Scotland.gov.uk/publications> (consulted on 27 April 2012).

13. M. Settle, "SNP snub plan for more taw powers at Holyrood", The Herald, Monday 21 January 2013. 
Assembly has had to wait for the 2011 referendum held in Wales to be given the go-ahead for full law-making powers - though this would be limited to its 20 devolved areas and would not be a general legislative power. As Scotland is now moving towards a form of financial autonomy, it seemed difficult for Wales to avoid the debate, all the more since while the practical effect of the Scotland Act is primarily on Scotland, it extends to the whole of the UK. The Silk Commission report to which the government had to respond at the start of 2013, suggested a bold step forward for Wales. A Welsh legal system could follow. So the case for Wales is now looming.

\section{The Scotland Act and its potential impact on Wales}

The original statute introducing devolution in Wales, the Government of Wales Act 1998 - following the referendum held in September 1997 led to the creation of the National Assembly for Wales, which inherited the executive powers of the Secretary of State for Wales. From the very beginning, the devolution settlement for Wales was considered as inadequate from a political and economic viewpoint since Wales, unlike Scotland, has been permanently underfunded. The Scotland Act has revived the debate in Wales about the unfairness of the Welsh devolved settlement and has led Wales to push for fair funding and borrowing powers, all the more so since Labour returned to power in the 2011 Welsh Assembly elections. As the Labour First Minister for Wales Carwyn Jones stated in the speech "Wales and the future of the UK" delivered on 30 March 2012: "We cannot go forward with fiscal devolution without fair funding." The debate about the inadequacy and unfairness of devolution arrangements for Wales was far from being a new one.

Indeed, shortly after the implementation of devolution in Wales, an independent expert commission, the Commission on the Powers and Electoral Arrangements of the National Assembly for Wales, also known as the Richard Commission, had been set up to review devolution in Wales. In its report published in 2004 it focused on the need to separate the executive from the legislative in Wales and to grant primary legislative power to the Welsh Assembly. It was highly critical of the devolution settlement for Wales and advocated substantial changes but it only partly inspired the second devolution statute for Wales, the Government of Wales Act 2006. It set up a slow and complicated process of governance for the Welsh Assembly through Orders in Council following approval of legislative competence. So trying to gain primary legislative power for the National Assembly was seen as a priority and prevailed over the 
need to obtain financial or taxation power. The Government of Wales Act 2006, which was only partly a legislative response to the Richard Report, led to the formal separation - although such a separation had existed in practice since 2002 - between the executive functions and other functions of the National Assembly, creating the Welsh Assembly Government with executive powers exercised by the Welsh ministers. The Jones-Parry Commission of 2009 meanwhile formally called for a Welsh referendum on legislative powers. While granting these powers to the National Assembly in the wake of the success of the 2011 Welsh referendum was perceived as a major step towards greater devolution there, the absence of a clear connection between Welsh taxpayers, the Welsh economy and the resources available to the Assembly Government continued to be seen as an anomaly. Under the current system, resources allocated through the Barnett Formula are the largest single component of public spending in Wales. The National Assembly has no tax-varying powers and Welsh ministers only have limited borrowing powers. The aggravation of the decline in relative funding per head in Wales led to a growing awareness of the need to review the funding of devolution in Wales.

\section{The Holtham Commission more radical than Calman}

In 2008, the Independent Commission on Funding and Finance for Wales - named after its Chairman Gerry Holtham — was set up to examine how Wales was funded as a result of an agreement - the "One Wales Agreement"- between the Labour and Plaid Cymru groups in the National Assembly after the launch of a Labour-Plaid coalition. As it is explained in its final report published in July 2010:

Taxes raised in Wales (excluding Council tax and non-domestic rates) are pooled at the UK level, from which the UK Parliament provides a sum of money to the Assembly Government to fund devolved activities. Welsh ministers have discretion over how these funds are allocated but are not able to alter the overall size of the budget by raising or reducing tax.

The terms of reference of the Holtham Commission were twofold:

To look at the pros and cons of the present formula-based approach to the distribution of public expenditure resources to the Welsh Assembly Government and identify possible alternative funding mechanisms including the scope for the Welsh Assembly Government to have tax varying powers as well as greater powers to borrow. ${ }^{14}$

14. Independent Commission on Funding and Finance for Wales, Fairness and Accountability: a new funding settlement for Wales, Final Report, July 2010, chapter 1, 1.1, p. 3. 
Its first report looked at the pros and cons of the present formulabased approach to the distribution of public expenditure resources to the Welsh Assembly Government whereas its second and final report published in July 2010 tried to identify possible alternative funding mechanisms including the scope for the Welsh Assembly Government to have tax-varying powers as well as greater powers to borrow. The Holtham Commission - like the Calman Commission for Scotland before it reached the conclusion that devolved government should be funded by a combination of a block grant, calculated on the basis of relative needs, and own-source tax revenues, mainly personal income tax. Like Calman, the Holtham Commission also recommended a borrowing power to finance capital expenditure. As it is acknowledged by Holtham, further financial devolution for Scotland was perceived as an incentive in Wales in order to go further with the Welsh devolution settlement:

The preparatory work that is under way to implement tax devolution for

Scotland should proceed on the assumption that similar tax powers could be devolved to Wales. ${ }^{15}$

In fact, it should be noted that, in some ways, Holtham was more radical than Calman as it considered, for example, granting Wales not only its share of income tax but also power over corporation tax, a very controversial proposal.

\section{The review of Devolution in Wales through the Silk Commission}

The Silk Commission was notably in charge of looking at the financial relationship between Wales and Westminster - a theme given added urgency by the recent severe public sector cuts which had particular impact on Wales - and of providing a wider review of devolution in Wales. It included two independent members and four party political nominees. The Silk Commission is looking at the case for devolution of further fiscal powers to Wales and will also examine the constitutional settlement for Wales. The Silk Commission had to complete its work on the fiscal side of the Welsh devolution on the financial accountability of the National Assembly for Wales, by the autumn of 2012-and did so-before reporting on the powers of the Assembly and in particular the boundary between what is devolved and non-devolved including issues relating to the election of Assembly Members by Spring 2014.

15. House of Commons Library, Holtham Commission, SN/EP/6288, 1 November 2012, 5.4, p. 6. 


\section{Conclusion: The impending independence referendum on Scotland}

An agreement was struck between the Scottish Government and the UK Coalition Government over the contents of the Act and was confirmed by the Secretary of State in a written statement on 21 March 2012. What is more, the Scottish Parliament itself passed the Legislative Consent Motion for the Scotland Act unanimously on 18 April 2012. ${ }^{16}$ The provisions of the Scotland Act will not come fully into force until 2016, that is to say after the referendum on Scotland, which is due to be held in 2014.

The referendum on the independence of Scotland loomed large over the debates on the Scotland Act-following the SNP's overwhelming victory in the last Scottish parliamentary elections in 2011. In the Lords debates, Lord Steel argued that a statement about the timing and nature of a referendum on Scottish independence should be inserted in the Act. Scotland should not be "sleep-walking into independence".

The Scotland Act is not enough for the SNP, but too much for some unionists. Alex Salmond, the leader of the SNP and Scotland's First Minister, seeks maximum devolution with full fiscal autonomy-he wants the Scottish Parliament to have control over all income tax as well as corporation tax. He promotes financial autonomy as a step to independence whereas devolutionists support full fiscal autonomy as a step towards a federal UK. Yet, all agree on the fact that Scotland is still highly centralized in spite of devolution. The SNP Government under Alex Salmond initially proposed including side by side in the referendum a proposal for total Scottish independence with one for "devo max", that is to say a proposal for full Scottish financial and fiscal autonomy within the framework of the UK, a proposal that was resisted by the Westminster government despite (or perhaps because of) the fact that polls show that most Scottish electors support it, as does much of the Scottish media. ${ }^{17}$ However, on 14 October 2012 a deal between the British Prime Minister David Cameron and the Scottish First Minister Alex Salmond was reached, settling the terms for a Scotland-wide referendum on the issue of independence to be held in $2014 .{ }^{18}$ On the one hand, the legal authority to hold this referendum is to be temporarily transferred by the Westminster Parliament

16. This was necessary since the Scotland Act was subject to the Sewel Motion, as the Westminster Parliament, though sovereign, is not supposed to legislate on devolved matters in Scotland without the consent of the Scottish Parliament. The latter takes the form of a Legislative Consent Motion.

17. See the article by D. Maddox, "Scottish Independence: Leaders share their vision for Scotland in-or-out of Union", The Scotsman, 31 December 2012.

18. In 2014, Scotland will host several high profile cultural and sporting events and the country will mark the 700th anniversary of the famous Scottish victory over the English known as the battle of Bannockburn. 
to Holyrood under a sunset clause ${ }^{19}$ (as it is normally part of the reserved powers) andthe Scottish legislature will be in charge of deciding the date, the question and qualifications for the franchise for the referendum. In exchange, Alex Salmond accepted that only a single yes-or-no question on Scottish independence should be asked (as wanted by the British Coalition Government), which forces the issue into Black and White, and the whole process will be overseen by the UK Electoral Commission.

As with so much else regarding devolution, the United Kingdom is engaged in a process, not an event, and the long-term outcome for the constitutional structure of the whole United Kingdom remains uncertain. The Scotland Act, perhaps unwittingly, may be the trigger that will take the debate onto a new, more controversial and even dangerous path. It might not lead to an independent Scotland but instead to that "looser Union", which Carwyn Jones foresees as its future. In an era of pressure for national autonomy in Europe (Spain, Belgium, even Italy), we may be on the way to a confederal Britain.

\section{Selective bibliography}

\section{Books}

Bondway Robin and Shah Anwar, Fiscal Federalism: Principles and Practice of Multiorder Governance, Cambridge, Cambridge University Press, 2009.

Givardi Christian, L'Écosse contemporaine, Paris, Ellipses, 2002.

Finding Susan, Jones Moya, and Cauvet Philippe, "Unfinished Business" Governance and the Four Nations: Devolution in the UK, Presses universitaires de Bordeaux, 2011.

Girard Gaïd and Graves Matthew (eds), Europe unie : Le Royaume désuni? Les enjeux de la dévolution, Brest, Université de Bretagne occidentale, 2000.

Leydier Gilles (dir.), La dynamique de la dévolution au Royaume-Uni, Babel, no. 17, Université du Sud-Toulon Var, 2008.

Oliver Dawn and Drewry Gavin, The Law of Parliament, Cambridge, Cambridge University Press, 1998.

O’Neill Michael, Devolution and British Politics, London, Pearson-Longman, 2004.

19. A sunset clause or provision is a measure within a statute, or other law that provides that the law shall cease to have effect after a specific date (here at the end of 2014), unless further legislative action is taken to extend the law. 
Osmond John (ed.), Welsh Politics Come of Age, Cardiff, IWA, 2005.

TAYlor Alan, What a State! Is Devolution for Scotland the end of Britain?, London, Harper Collins, 2000.

Trench Alan, Devolution and power in the UK, Manchester, Manchester University Press, 2007.

\section{Articles}

Foulkes of Gumnock (Lord), "Crunch vote Scotland Bill", The House Magazine, 23 February 2012, pp. 14-5.

Holтнам Gerry, "Not fit for purpose", Bevan Foundation Review, no. 14, 2010, pp. 4-5.

_, "Time to be bold", Institute of Welsh Affairs (IWA), no. 44, 2011, pp. $30-1$.

\section{Press articles}

Arlidge John, "Breaking up Britain”, The Sunday Times, 27 May 2012.

MADDox David, "Scottish Independence: Leaders share their vision for Scotland in-or-out of Union", The Scotsman, 31 December 2012.

SETTLE Michael, "SNP snub plan for more tax powers at Holyrood", The Herald, 21 January 2013.

\section{Official documents}

Commission on Scottish Devolution, Serving Scotland Better; Scotland and the United Kingdom in the 21st century, June 2009.

HM Government, The Coalition: Our Programme for Government, London, Cabinet Office, May 2010.

HM Treasury, Funding the Scottish Parliament, National Assembly for Wales and Northern Ireland Assembly: statement of funding policy, October 2010.

House of Commons Library, Devolution in Wales: The Silk Commission, SN/PG/06108, London, 2012.

-, Devolution of tax powers to the Scottish Parliament, 14 June 2011, SN/ BT/5984, London, 2011.

House of Lords Library Note, Scotland Bill, HL Bill 79 of 2010-2012, London, 2012.

—, The Barnett Formula, HL Paper 139, July 2009.

Independent Commission on Funding \& Finance for Wales, Fairness and accountability: a new funding settlement for Wales, Final Report, July 2010.

Institute of Welsh Affairs, Steps on the road to fiscal federalism, clickonwales, 17 May 2011. 
ÉTUDES ÉCOSSAISES 16

Scotland Office, Strengthening Scotland's Future, Cm 7973, November 2010.

-, Scotland's future in the United Kingdom: building on ten years of Scottish devolution, Cm 7738, 25 November 2009.

The Stationary Office, Scotland Bill, HL Bill 79, 22 June 2011, London, 2011. 